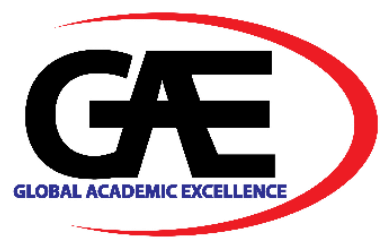

\title{
KNOWLEDGE MANAGEMENT PROCESS IMPLEMENTATION IN PRIVATE FINANCE INITIATIVE PROJECT IN MALAYSIA
}

\author{
Kumalasari Kipli $^{1 *}$, Fara Diva Mustapa ${ }^{2}$, Shariffah Zatil Hidayah Syed Jamaluddin ${ }^{3}$,Favilla Zaini ${ }^{4}$ \\ 1 Faculty of Architecture, Planning and Surveying, Universiti Teknologi Mara, Sarawak Branch, Malaysia \\ Email: kumalasari@uitm.edu.my \\ 2 Fakulti Alam Bina dan Ukur, Universiti Teknologi Malaysia, Malaysia \\ Email: faradiva@utm.my \\ 3 Faculty of Architecture, Planning and Surveying, Universiti Teknologi Mara Shah Alam, Malaysia \\ Email: shariffah254@uitm.edu.my \\ 4 Faculty of Information Management, Universiti Teknologi Mara, Sarawak Branch, Malaysia \\ Email: favilla@uitm.edu.my \\ Corresponding Author
}

\section{Article Info:}

Article history:

Received date: 01.10 .2021

Revised date: 01.11 .2021

Accepted date: 20.11 .2021

Published date: 01.12.2021

To cite this document:

Kipli, K., Mustapa, F. D., Jamaluddin, S. Z. H. S., \& Zaini, F. (2021). Knowledge Management Process Implementation In Private Finance Initiative Project In Malaysia. Journal of Information System and Technology Management, 6 (24), 109-117.

\section{DOI: $10.35631 / J I S T M .624011$}

This work is licensed under CC BY 4.0

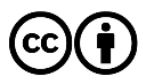

\begin{abstract}
:
PFI involved a project with long-term relationships at various stages from pre-contract stage to contractual stage and in use stage which also include maintenance stage. $\mathrm{KM}$ process is one of the elements to ensure the success of the KM system. In the PFI project, the KM process also needs to be checked whether it is applied in the various stage of the pre-contract stages. Questionnaires had been distributed to the parties involved at the pre-contract stage. The results are then analyse using the Relative Important Index (RII) to identify the ranking of KM usage in various stages of the pre-contract stage. According to the analysis, some of the stages in the pre-contract process of the PFI are not fully implemented in the KM process. For knowledge acquisition and storage practise, the high usage of the process is at the conduct of value management, submission to cabinet and access, evaluation, and approval. The next KM process which is capturing and storing, the process evaluation, negotiation and recommend are the activities at the higher level practising these $\mathrm{KM}$ processes. At next $\mathrm{KM}$ process which is re-using and sharing are Access and approval by the ministry, evaluation, negotiate and recommend practise more on this KM process.
\end{abstract}

Keywords:

Project Finance Initiative (PFI), Pre-Contract Stage, Knowledge Management System, Knowledge Management Process 


\section{Introduction}

The first Malaysian version of PFI was financed by the employee provident fund (EPF) loans. Nevertheless, there is a view that the government could still bear the risk to a certain extent, in particular, if any of the PFI projects becomes unsuccessful. Although the PFI may have been tested for more than a decade in developed countries such as the UK, Australia, US and others, the appreciation of it is relatively new in Malaysia and introduced in the year 2006.

Knowledge management has emerged as a major driving force to achieve objectives. Knowledge management is a process of acquiring, creating, sharing, utilizing and storing intellectual assets and other stimuli from the internal and external business environments that facilitates an organization to perform successfully (Huber, 1991;Badi \& Murtagh, 2019). By improving the value of knowledge as assets, it drives the organization's success.

According to Carrillo et al., (2006) decisions on what knowledge a construction organisation needs or the knowledge intensity depends on the context of the business environment, i.e. key knowledge about processes and people for the delivery of its products. These context-based factors address issues of what is produced (products-goods/services), how it is produced (processes) and by whom (people). There are therefore three aspects of knowledge to manage in the construction context: (1) products or project types, (2) processes, and (3) people (see Figure 1). The knowledge base of construction organizations is a function of the procedures put in place to capture knowledge about processes, products, as well as people because knowledge primarily resides in people, not technology (Davenport, 2000). Technology supports connectivity; it is, therefore, an important enabler to support the KM process.

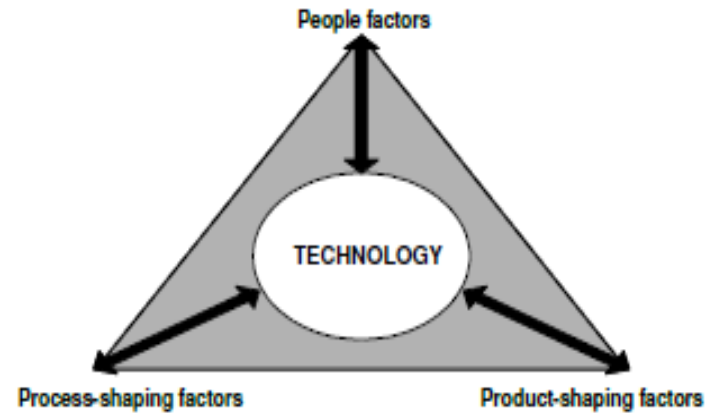

Figure 1:Context-Based Factors Influencing A KM Strategy

Source: Chimay J. Anumba, et al., 2005) (Reproduced by Chimay J. Anumba, et al., (2005), with permission by Robinson et al., 2001)

\section{Methodology}

The methodology adapts in this research is using literature to collect all the possible answers to be asked in the questionnaires(Kamar, K. A. M., Alshawi, M. and Hamid, 2010; Musawa \& Ahmad, 2017; Wang et al., 2015). The population of this research are the employees from the 20 PFI projects listed under Public Private Partnership unit (UKAS), which comprise of different professionals with different areas of specialization and working together under the PFI projects. 
The sample size determines by using simple random sampling where we assume every party in the 20 projects has an equal chance of answering the questionnaires distributed. Random sampling use in this research because random sampling is where each member of a population has a known and non-zero probability of being included in the sample. If a sample of size $\mathrm{n}$ is taken an infinite number of times from a population by a random sampling method, the distribution of the sample means is the sampling distribution of the mean(Fellows \& Liu, 2003). As for this research, the questionnaires distribute to Civil Engineers, Mechanical and Electrical Managers, Quantity Surveyors, Architects, Projects Directors, Project Managers, Building Surveyors and Technical Assistant involved in each project and a total of 160 questionnaires distribute including those working with UKAS, Ministry of Finance, Ministry of Higher Education, Economic Planning Unit (EPU) and other related agencies.

As for the data analysis, the Relative Importance Index (RII) is being used to find the most suitable analysis(Henjewele et al., 2012;Zawawi et al., 2014;Abdullahi Ahmed Umar et al., 2013;A.A. Umar et al., 2013;Zhou et al., 2014). The RII was used to rank the benefits as perceived by the respondents. The priorities (relative importance weights) must be established for each set of elements at every stage of the hierarchy. Finally, the weighted evaluation of each alternative is obtained by summing the weighted scores (by multiplying the priority weight and the evaluation rating) of all attributes(Fellows \& Liu, 2003).

\section{Main Result}

Table 1: The Designation Of The Research Respondents

\begin{tabular}{|c|c|c|}
\hline Designation & Frequency & Percentage \% \\
\hline Project Director & 6 & 5.0 \\
\hline Project Manager & 6 & 5.0 \\
\hline Architect & 6 & 5.0 \\
\hline Quantity Surveyor & 18 & 15.0 \\
\hline Electrical and Mechanical Engineer & 18 & 15.0 \\
\hline Civil and Structural Engineer & 48 & 40.0 \\
\hline Technical Assistant & 12 & 10.0 \\
\hline Building Surveyor & 6 & 5.0 \\
\hline Total & $\mathbf{1 2 0}$ & $\mathbf{1 0 0}$ \\
\hline
\end{tabular}


From 120 questionnaires returned, it can be deduced that $40 \%$ of the total respondents are Civil and Structural Engineers, Project Manager 5\%, Project Director 5\%, 15\% Quantity surveyors, 5\% Architects, 5\% Building Surveyors, 15\% Mechanical and Electrical Engineers and $10 \%$ are technical assistants.

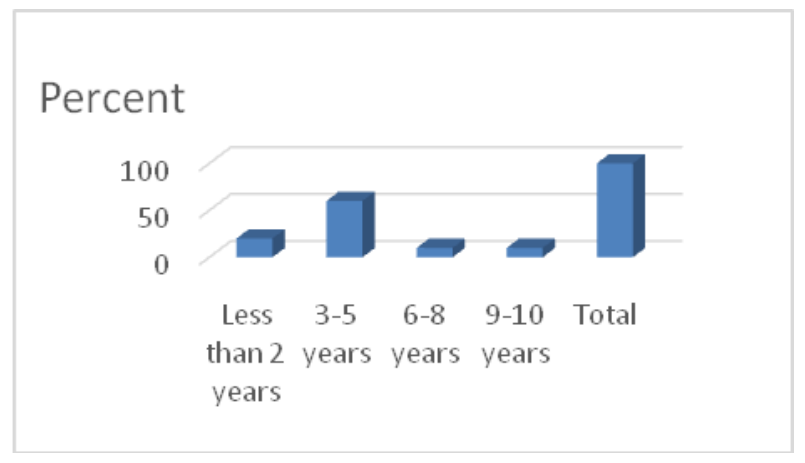

\section{Figure 2: The Respondents Working Experience In PFI Projects}

According to Figure 2, most of the respondents who are around $60 \%$ have 3-5 years of working experience in PFI projects. $10 \%$ of them have 6-8 years of working experience in PFI, another $10 \%$ of them have 9-10 years working experience in PFI and lastly, $20 \%$ have less than 2 years working experience in PFI.

The result in Table 2 shows the level of implementation of KM process in the various stage during the pre-contract of PFI projects. The results analyse using RII. From the table, we can see the various result on the level of implementation. In setting the decision rule for identifying factors that contribute significantly to variance in rateable values, the RII figure was classified into two groups of 'accept' and 'reject' as shown in Table 2. In this analysis, the highest RII was 0.85 and the lowest was 0.42 . The range of the RII was 0.42 to 0.85 .

The decision rule was that only those where the RII score fell within the very significant and the extremely significant were considered to contribute significantly to variance in rateable values. This type of decision rule was used by (Gunduz \& Yahya, 2018; Ismail, 2015).

The result of the application of RII decision rule of Table 2 is presented in Table 3.

Table 2: Decision rule for RII analysis

\begin{tabular}{|c|c|c|}
\hline Scale Of Index & Range Of Index & Decision Rule \\
\hline Not At All Significant & 0.42 To 0.52 & Reject \\
\hline Slightly Significant & 0.53 To 0.63 & Reject \\
\hline Some What Significant & 0.64 To 0.74 & Reject \\
\hline Very Significant & 0.75 To 0.86 & Accept \\
\hline Extremely Significant & 0.87 To 0.98 & Accept \\
\hline
\end{tabular}


For knowledge re-using and sharing the respondents answered that it is Easy to understand the item, the RII is 0.75 , and the stage above 0.75 are stage 2,3,4,7 and 9. Easy to retrieve an item, the RII is 0.78 . The stages which are above 0.78 are stage $2,4,9$ and 10.

For Knowledge Capturing and Storing RII for item "Assigned a person to take records of past projects data/information, and reports of site meeting" is 0.77 . The stage which relatively important is stage 2, 7, 10. While for Knowledge reusing and sharing RII for "Reviewing data/information, best practice and experiences from past projects contents and experts" is 0.76. The stages in which the RII more than 0.76 is $2,7,9$ and 10 . For item "Classifying data/information, best practices, and experiences of past projects to facilitate recording and searching" the RII is 0.72 , and the stages which above this RII are 2, 4, 7, and 10 . The item "Capturing data and information of projects in the electronic repository (database)" RII is 0.72 and the stages above this RII are 2, 4, 7, and 9.

\section{Conclusion}

The knowledge process in PFI Project for the pre-contract stage is still not fully implemented at certain procedures. For knowledge acquisition and storage practice, the high usage of the process is at the conduct of value management, submission to the cabinet, and access, evaluation, and approval. The next KM process which is capturing and storing, the process evaluation, negotiation, and recommend are the activities at the higher level practicing these $\mathrm{KM}$ processes. At next KM process which is re-using and sharing are Access and approval by the ministry, evaluation, negotiate and recommend practise more on this KM process.

\section{Acknowledgement}

I would like to express my appreciation to all the parties involved in answering the questionnaires.

\section{References}

Badi, S., \& Murtagh, N. (2019). Green supply chain management in construction: A systematic literature review and future research agenda. Journal of Cleaner Production, 223, 312-322. https://doi.org/10.1016/j.jclepro.2019.03.132

Carrillo, P. M., Robinson, H. S., Anumba, C. J., \& Nasreddine, M. (2006). Construction Management and Economics A Knowledge Transfer Framework: the PFI context A Knowledge Transfer Framework: the PFI context. December 2014, 37-41. https://doi.org/10.1080/01446190600799224

Fellows, R., \& Liu, A. (2003). Research Methods for Construction. In Quarterly Journal of Economics. http://books.google.com/books?id=FTaNfk6Z_xMC\&pgis=1

Gunduz, M., \& Yahya, A. M. A. (2018). Analysis of project success factors in construction industry. Technological and Economic Development of Economy, 24(1), 67-80. https://doi.org/10.3846/20294913.2015.1074129

Henjewele, C., Sun, M., \& Fewings, P. (2012). Analysis of factors affecting value for money in UK PFI projects. Journal of Financial Management of Property and Construction, 17(1), 9-28. https://doi.org/10.1108/13664381211211028

Ismail, A. (2015). Factor Affecting the Housing Financing of Bumiputera in Iskandar Malaysia. Journal of Economics, Business and Management, 3(11), 1031-1036. https://doi.org/10.7763/joebm.2015.v3.329 
Volume 6 Issue 24 (December 2021) PP. 109-117 DOI: 10.35631/JISTM.624011

Kamar, K. A. M., Alshawi, M. and Hamid, Z. (2010). BARRIERS TO INDUSTRIALIZED BUILDING SYSTEM ( IBS ): THE CASE OF MALAYSIA The Problem Statement Research Methodology This paper is a preliminary study to a PhD research on Industrialised Building System. 2009.

Musawa, M. S., \& Ahmad, H. (2017). Disclosure of public-private partnership ( PPP ) voluntary information Case of Malaysian PPP projects. https://doi.org/10.1108/APJBA-10-2016-0095

Robinson,H.S., Carrillo,P.M., Anumba,C.J. and Al-Ghassani, A.M. (2005), Knowledge management practices in large construction organisations, Engineering, Construction and Architectural Management, 12(5), pp. 431-445.

Thomas H Davenport (2000), Mission critical: realizing the promise of enterprise systems, Harvard Business Pre.

Umar, A.A., Zawawi, N. A. W. A., Khamidi, M. F., \& Idrus, A. (2013). Stakeholder perceptions on achieved benefits of PFI procurement strategy. Modern Applied Science, 7(4). https://doi.org/10.5539/mas.v7n4p31

Umar, Abdullahi Ahmed, Idrus, A., Khamidi, M. F., Iskandar, B. S., \& Darul, P. (2011). Barriers to the use of Public-Private Partnerships for provision of Public Infrastructure in Developing countries : A review.

Wang, C., Kam, K., \& Liew, S. A. (2015). Determinants of Knowledge Sharing Culture in Malaysian Technology Firms. February.

Zawawi, N. A. W. A., Umar, A. A., Aziz, A. R. A., Crouzier, O., Khamidi, M. F., \& Idrus, A. (2014). PFI Procurement Skills: A Cross-sector Survey of Practitioners. Procedia Engineering, 77, 170-178. https://doi.org/10.1016/j.proeng.2014.07.016

Zhou, L., Keivani, R., \& Kurul, E. (2014). Sustainability performance measurement framework for PFI projects in the UK. https://doi.org/10.1108/JFMPC-08-2012-0032 
Volume 6 Issue 24 (December 2021) PP. 109-117

Table 3: Level Of Implementation Of Knowledge Management

DOI: 10.35631/JISTM.624011

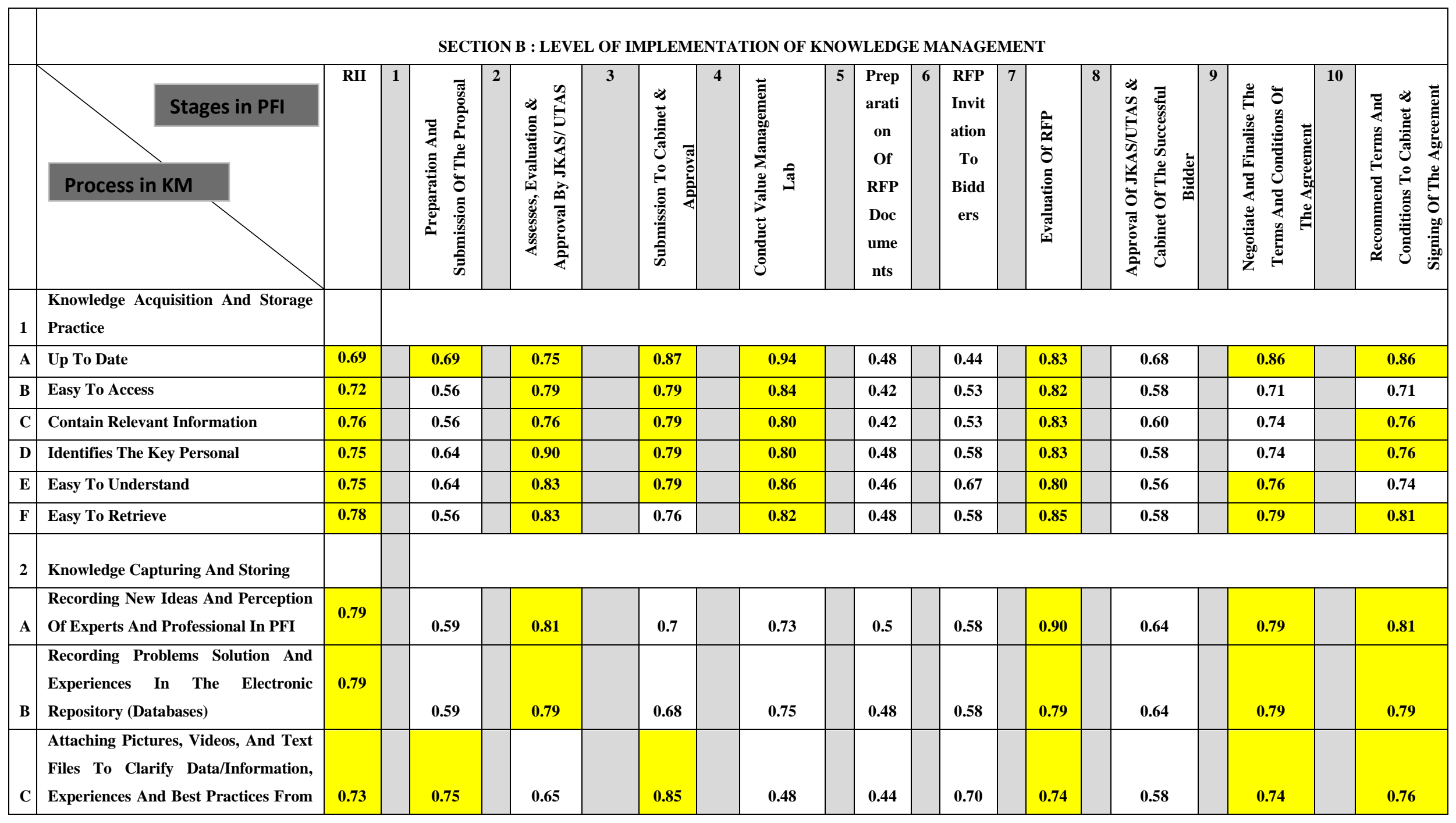

Copyright $\odot$ GLOBAL ACADEMIC EXCELLENCE (M) SDN BHD - All rights reserved 
Volume 6 Issue 24 (December 2021) PP. 109-117

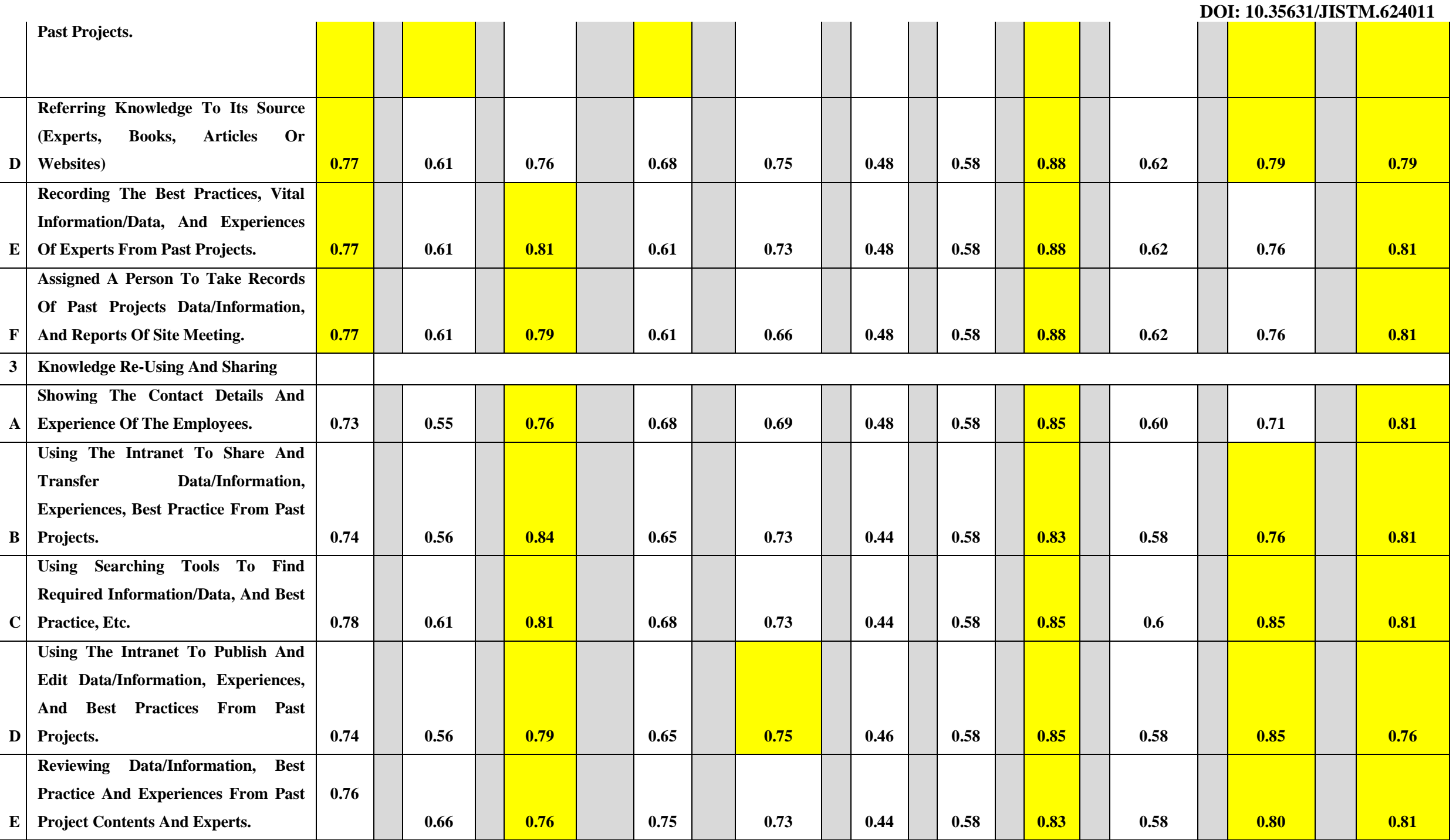


Volume 6 Issue 24 (December 2021) PP. 109-117

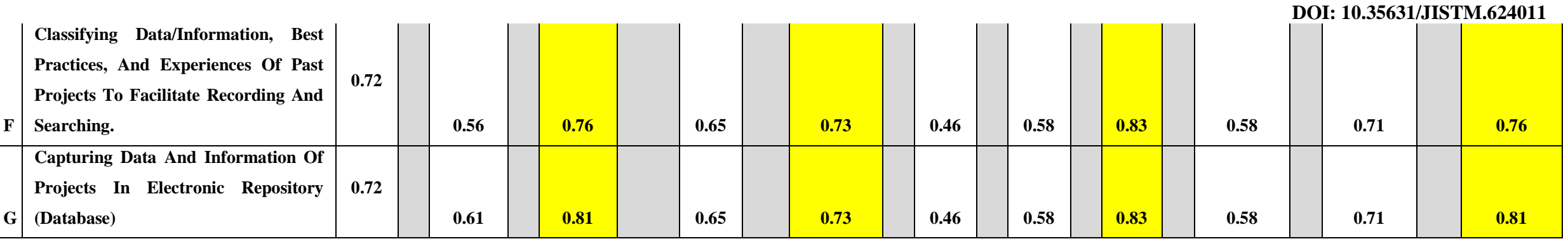

